\title{
Gay Lotharios and Innocent Eves: Child Maintenance, Masculinities and the Action for Breach of Promise of Marriage in Colonial Australia
}

\author{
Alecia Simmonds
}

\begin{abstract}
This article will focus upon the action for breach of promise of marriage in colonial Australia to reflect more broadly on the legal regulation of intimacy. Drawing upon a database of 211 breach of promise cases, I seek to explain a contradiction: almost half of the female plaintiffs in my study had illegitimate children, although a lack of virtue operated as a complete defence for (predominantly) male defendants. In spite of this, a vast majority of the women were successful. This paradox is clarified through an examination of the action in contract treatises and through an analysis of the way that the action operated as a supplement to maintenance for women with children. I conclude with a close study of a breach of promise case involving illegitimacy, as a means of examining the informal and formal norms governing love (and its discontents) in colonial Australia
\end{abstract}

\section{INTRODUCTION}

Bravo flew to the finish line in a remarkable gallop. Mark Twain was at the Melbourne Cup Race that year, 1889, delighting in 'the conflagration of preparation and anticipation and jubilation'. 'John Duggan, an engine driver from the small New South Wales town of Teralba, was also there gripping a sweepstake ticket worth 30,000 pounds for Bravo in his hand. The ticket would transform Duggan from labourer to lord. Or so he thought.

Esther Maria Stewart - domestic servant, single mother and resident of Newcastle's Benevolent Asylum - must have been equally excited by Bravo's win. She had met Duggan as a frolicsome 18 year old, swishing her way around the Teralba dances. For five months Esther and John 'walked out together'. She once resisted 'an indecent proposal' but eventually acquiesced after he promised her marriage. 'Only fancy if father finds out,' she gasped, and sure enough he did. A few months later Esther became pregnant; her swelling body eyed with alarm by family and friends. They greeted its growth with murmurs of loss: loss of reputation, income, and respectability.

An informal court of love was called. Stewart's sister summonsed Duggan to her house. 'I suppose you know what I have sent you for', she

$1 \quad$ Mark Twain, The Wayward Tourist: Mark Twain's Adventures in Australia (Melbourne University Press, 2006) 61. 
snapped, and demanded that Duggan marry Stewart 'for the sake of self and family'. Esther also demanded a fulfilment of promise. Duggan replied that he 'would never deceive her, but would marry her' and reassured Esther's sister that the marriage would be within two months. Esther returned home to her family, and upon the death of her father was sent to Newcastle's Benevolent Asylum where she gave birth. When Duggan came to visit Esther he was interrogated by the matron as to his intentions, and Duggan again pleaded lack of means. It was the depression and like many labouring men, he was condemned to nomadism in his search for work while Stewart, like many single mothers, was condemned to stasis by the labour of care.

For two and a half years Esther heard nothing of Duggan. She worked from 5 in the morning till 10.30 at night, washing clothes for 4 shillings a day. When Duggan returned to Newcastle she flew to her letter book and wrote him a love letter. He responded in kind, but complained that 'it would cost [him] a nice lot of money to get married and settle here'. He made reference to some 'yarns' he had heard about her in Teralba, but promised her marriage and signed off with abundant kisses for Esther 'and my son'. One month later, when a 'nice lot of money' arrived, Duggan disappeared.

Stewart tracked down Duggan, orchestrated his arrest under a writ of capius and sued him for maintenance. She was awarded 15 shillings per week for 12 months. Five months later she sued Duggan for breach of promise of marriage. The hearing was conducted before a crowded courtroom who chortled at his effusive letters and signature kisses. Stewart also had to answer to Duggan's plea that she was 'immodest, unchaste and immoral'. Yes, she was fond of dancing. No, she had never asked a man to go to a ball or buy her gloves. Yes she did know Castor Jones but had never said that 'she would sooner have Castor Jones' little finger than Duggans' whole body. And yes, she did throw a bottle at a man at 2 in the morning after a ball, but this was because he was singing an indecent song. ${ }^{2}$

The judge told the jury that 'the matter was really a claim for loss of a husband' and the fact that Duggan had a large sum of money 'was a good ground of action'. It seemed that Stewart couldn't lose: 'if they were satisfied that the plaintiff was chaste, she was entitled to recover'. If they believed that Duggan never intended to marry her, then it must be 'the most infamous and cold-blooded seduction'. The jury, after 12 minutes of deliberation, awarded Stewart the 1000 pounds she claimed and the judge ordered an immediate transfer to her of the money. ${ }^{3}$

2 'Civil Side', Newcastle Morning Herald and Miners' Advocate (Newcastle) 16 April 1890, 7; 'The Big Sweep Winner', Singleton Argus (New South Wales), 11 December 1889, 4; 'Law Report' Sydney Morning Herald (Sydney), 29 April 1890, 4; 'Maitland Circuit Court' Maitland Mercury and Hunter River General Advertiser (New South Wales), 17 April 1890, 3.

$3 \quad$ Stewart v Duggan [1890] NSWSupC 3 (Foster J); see Stewart v Duggan, 'Index to Judgment Books: Civil Jurisdiction', State Records Office NSW, 9/917 (1890); 'Judgment Papers' Container 20/11055 (second term) No 143; Notebooks: Civil Causes (Chief Justice Forster) 1886-1906 (2/2851). The judgment papers for this 
Stewart $v$ Duggan is typical of the 211 breach of promise of marriage cases I have examined from 1825-1900. As feminist historian Ginger Frost has noted, litigants were primarily drawn from the lower-middle classes and the respectable working classes. Like Stewart they were women 'who had supported themselves for years' and whose 'courtships were quite long and protracted with painful separations'. ${ }^{4}$ Like other working women, Stewart had every reason to ignore the middle class criticisms of the suit; criticisms that legal historians Saskia Lettmaier ${ }^{5}$ and Rosemary Coombe $^{6}$ have described in their work. They argue that the suit was seen by bourgeois commentators as a dangerous commercial encroachment into a sanctified private sphere. It paradoxically demanded that women prove their virtue and modesty through aggressively pursuing men for money in a public arena. Duggan's defence, that Stewart was unchaste and immoral, backed up by gossip and 'yarns' was also predictable and speaks to Kirsten McKenzie's observation that the action converted women's sexual reputation into economic value. ${ }^{7}$ As Constance Backhouse has argued, in a world where marriage was women's only respectable vocation, a broken promise and a seduction, meant real economic and social loss. ${ }^{8}$

While feminist and legal historians have unpicked the suit's significance for working class women generally, the role that the suit played as a supplement to maintenance is yet to be examined. Breach of promise of marriage receives little mention in histories of single mothers and is barely discussed in histories of the development of welfare. This may be because studies of maintenance and welfare have tended to focus on deserted wives rather than single women. ${ }^{9}$ Yet, as Bruce Kercher has shown, the early colonial courts enforced maintenance payments for both legitimate and illegitimate children, long before the Deserted Wives

case are particularly voluminous, containing the love letters that Stewart wrote to Duggan, her train ticket to Sydney and a typed transcript of the trial. The notebook, however, contained nothing on the case.

4 Ginger Frost, 'I Shall Not Sit Down and Crie: Women, Class and Breach of Promise of Marriage Plaintiffs in England, 1850-1900' (1994) 6(2) Gender and History 225.

5 Saskia Lettmaier, Broken Engagements: The Action for Breach of Promise of Marriage and the Feminine Ideal 1800-1940 (Oxford University Press, 2010) 73-78.

6 Rosemary Coombe, 'The Most Disgusting, Disgraceful and Iniquitous Proceeding in Our Law: The Action for Breach of Promise of Marriage in Nineteenth-Century Ontario' (1988) 38(1) University of Toronto Law Journal 65, 65-69.

$7 \quad$ Kirsten McKenzie, Scandal in the Colonies (Melbourne University Press, 2004) 105.

8 Constance Backhouse, Petticoats and Prejudice: Women and Law in Nineteenth Century Canada (Women's Press, 1991) 86.

9 Christina Twomey, Deserted and Destitute: Motherhood, Wife Desertion and Colonial Welfare (Australian Scholarly Press, 2002); Anne O'Brien, Poverty's Prison: The Poor in New South Wales 1880-1918 (Melbourne University Press, 1988); Susan Tiffin, In Whose Best Interest? Child Welfare Reform in the Progressive Era (Greenwood Press, 1982); Shurlee Swain, Single Mothers and their Children: Disposal, Punishment and Survival in Australia (Cambridge University Press, 1995). 
and Children Act 1840 (NSW) and its equivalents in other colonies were enacted. ${ }^{10}$ In my study, almost half of the women who sued for breach of promise of marriage successfully proved their chastity while carrying a child on their hip. In so doing, they made men financially responsible for illegitimate children: 'bastards' who according to common law at the time, 'hath no father' ${ }^{11}$ In the absence of poor law relief, where destitute women were reliant, to varying degrees across the colonies and across the century, upon the rations or indoor or outdoor relief provided by charitable and government institutions, ${ }^{12}$ the courts enforced a secular form of welfare through holding men to account. They stepped in, as Stewart v Duggan shows, when an elaborate system of informal community regulation failed; a system that itself borrowed heavily from formal law, but dispensed pleas and punishments in the realm of emotion. Letters appeared like judgments, parents like police, community like spies, and lovers like litigants. At stake was not just the reputation and livelihood of the woman and her family but also that of her suitor who was measured against a sentimental, breadwinner norm, appealed to as a man of feeling and in the final instance publicly punished for his transgressions.

This paper will focus on single mothers and colonial masculinities - two relatively unexamined aspects of the breach of promise action-to reflect more broadly on how laws in a plural sense, produce or prohibit models of gender and regulate intimacy. I move from an examination of the suit in legal treatises to an analysis of how breach of promise of marriage operated in colonial Australia through a basic statistical analysis of the 211 cases in my study. The final part of my paper narrows my focus to the issue of maintenance, examining the social and legislative context within which breach of promise of marriage operated. I conclude with a close study of a breach of promise case involving a woman who had given birth to an illegitimate child, as a means of examining the informal and formal norms governing love (and its discontents) in colonial Australia.

\section{Note On Sources}

The cases are drawn from a database which comprises every breach of promise case reported in Australian colonial newspapers, complemented, where possible, with archival research from the State Records of each Australian State. Formal law reporting (which only came to New South Wales in 1862 and to Victoria in 1876) is of little use for breach of promise of marriage cases as the cases are confined to those considered to be of

10 Bruce Kercher, An Unruly Child: A History of Law in Australia (Allen and Unwin, 1995) 51.

11 See Machon v Holt cited in Selden's Society Year Books of Henry VI, A.D. 1422 (CH Williams, 1933) 26.

12 See Brian Dickey, No Charity There: A Short History of Social Welfare in Australia (Allen and Unwin, 1987) 1-23; and for a South Australian perspective, Brian Dickey, Rations, Residence, Resources: A History of Social Welfare in South Australia Since 1836 (Wakefield Press, 1986). 
legal significance. ${ }^{13}$ Similarly, the State archives are porous and are generally only useful for the upper courts. The records left for matters heard in the District Courts or lower are very sketchy. I placed no limits upon my search for cases in Trove and found 8504 references to breach of promise in over two hundred newspapers. Of these, I found 211 cases, whose traces I then pursued in Judge's Notebooks, Deposition Papers and Judgment Papers in the State Archives. While this database is as conclusive as I can possibly make it, I would not claim that it is complete. To this extent, I am calling it a sample and my analysis, in any case, focuses more on the qualitative dimensions of the cases than the quantitative.

\section{Breach of Promise of Marriage in British Legal Treaties}

Breach of promise of marriage has its historical origins in medieval canon law that allowed jilted lovers to sue for specific performance, or enforcement of marriage. Hardwicke's Marriage Act of 1753 marked a turning point for the action as it shifted the jurisdiction of marriage from the ecclesiastic to the temporal courts and abolished the ecclesiastic courts' power to enforce marriage. After the passing of Hardwicke's Act, the civil law action for breach of promise of marriage was the only remedy available for those with a broken heart. ${ }^{14}$ It could be found nestled in contract treatises under the category of assumpsit - contracts without seal - although it borrowed its focus on injured feelings and the remedy of monetary damages from the law of torts.

The action for breach of promise of marriage required a mutual agreement to marry that had been unjustifiably broken. But the opacities of love made proving the agreement difficult. How was the law to convert the gestural vocabulary of courtship into disembodied legal code? How can two parties have mutually consented to a contract when the decision was sometimes left to the woman's parents? The problem was exacerbated by the inability of both plaintiff and defendant to give evidence until the 1870s for fear of perjury.

Nineteenth century legal commentators grappled with these interpretative problems. The 1807 treatise on contract law by Samuel Comyn assumed, in egalitarian spirit, that a contract would be formed when 'a man and a woman, being unmarried, mutually promise to marry each other'. ${ }^{15}$ In 1826 Joseph Chitty, the most prominent 19 th century contract law jurist required a 'general, yet definite and reciprocal understanding'

13 Michael Bryan, 'The Modern History of Law Reporting' (University of Melbourne Collections, 2012) 11. By 'legal significance' the author means that the case has developed or contributed to legal doctrine in some way.

14 I am indebted to Saskia Lettmaier for this research. See Lettmaier, above n 5, 19-24.

15 Samuel Comyn, A Treatise of the Law Relative to Contracts and Agreements Not Under Seal: with Cases and Decisions Thereon in the Action of Assumpsit, Volume 2 (A Strahan, 1807) 408. 
between the couple, that was known to their parents and friends, but added that the 'promise of a man' needed to be proved and evidence given that the woman had 'demeaned herself as if she concurred in and approved of his promise'. ${ }^{16}$ By 1872 Chitty's guidance had become more explicitly gendered and performative. A contract could be read into 'a man's visits to a woman and his declaration that he had promised to marry her'. ${ }^{17} \mathrm{~A}$ woman simply needed to concur, although it was important not to demand that this assent be too obvious. At a time when social order was seen to rest upon a separation between a virtuous private sphere and a morally corrupt public, there was considerable judicial anxiety over the social consequences of a clod-footed law trampling on the delicate shadow-lands of love. Was it necessary to have an express promise in direct terms? In 1872 Chitty cited Chief Justice Parker in Wightman v Coates (1818):

A necessity for this [explicit promise] would imply a state of public manners by no means desirable. That young persons of different sexes, instead of having their mutual engagements inferred from a course of devoted attention, and apparently exclusive attachment, which is now the common evidence, should be obliged, before they considered themselves bound, to call witnesses or execute instruments under hand and seal, would be destructive of that chaste and modest intercourse, which is the pride of the country, and a boldness of manners would probably succeed, by no means friendly to the character of the sex, or the interests of society. ${ }^{18}$

Here, Parker's words slide from a global concern about 'young persons of different sexes' to a very specific concern with 'the character of the sex', meaning women. Britain's claims to cultural distinction - 'the pride of the country' - according to Parker rested upon women's performance of moral superiority: their chaste and modest conduct in matters of the heart.

The suit thus shifted from an early romantic model of mutual promises to a model based on an active masculine subject who offers and a passive female subject who demurely accepts. Similarly, the primary defence to the suit-that you broke the promise because you had discovered your lover was of 'bad character'-changed over the course of the century from a focus on men and women to an exclusive focus on female chastity. Chitty's 1826 treatise uses as his example of 'bad character' a male plaintiff suing a female defendant who pleads that she broke her promise of marriage because the man was 'destitute of feeling' and had 'gross manners and sentiment'. The court found for the plaintiff on the grounds that the man suffered no injury, as he 'seemed little calculated to taste' the 'pleasures of her society'. ${ }^{19}$ By 1834 the man with gross manners had been joined by a 'loose and immodest woman' ${ }^{20}$ and by 1863 she had completely usurped

16 Joseph Chitty, A Practical Treatise on the Law of Contracts Not Under Seal, and Upon the Usual Defences to the Actions Thereon (G and C Merriam, 1826) 158.

17 Ibid, 587.

18 Wightman v Coates (1818) 15 Mass 4, Parker CJ; Chitty, above n 16, 585.

19 Chitty, above n 16, 159.

20 Joseph Chitty, A Practical Treatise on the Law of Contracts Not Under Seal: and Upon the Usual Defences to Actions Thereon with Corrections and Additional References by a Member of the Massachusetts (H Sweet, 1834) 428. 
him as the model of bad character. Chitty had revised his earlier approval of Lord Mansfield's dictum that any man is free to break off an engagement if he finds that 'her character turns out to be different from what he had reason to think it was' and instead cited authorities that this is only acceptable if there is a want of chastity on the part of the woman, or incapacity on the part of the man'. ${ }^{21}$

Crucially, there was an exception, or at least an ambiguity in the requirement of female chastity: if the suitor promised marriage in order to have sex with the woman then the promise was void and she was simply ruined. However, if he 'renewed his promise after the illicit intercourse had taken place then the subsequent promise will be binding'. ${ }^{22}$ In effect, this sanctioned pre-marital sex and legitimised children born out of wedlock, so long as marriage was to follow. In the instances that it didn't, breach of promise of marriage provided a crucial means for unwed mothers to gain a substantial lump sum maintenance payment. But unlike maintenance, the man could not plead bankruptcy or insolvency. As an offence involving malice and false pretences, or fraud, breach of promise of marriage joined libel, slander, seduction and criminal conversation as a category of offence for which a bankrupt could not be immediately discharged of his debts. In certain cases they were sent to prison and in others the debt remained. ${ }^{23}$

If we were to know nothing more of breach of promise of marriage than what was written in contract treatises then it would appear to be a strange mixture, for women at least, of sympathy and contempt, with more of the latter than the former. On the one hand, the action translated the sexual double standard into legally binding rules, presumed female dependence on men and stipulated female passivity in romantic love. It also admitted community gossip about sexual transgressions into evidence and it reduced a woman's economic and social worth to her sexual virtue. But on the other hand, the suit excluded sex under a continuous promise of marriage from the definition of unchastity and it offered women financial redress for broken vows. For men, it extended the virtue of promise-keeping, so crucial to definitions of masculine honour in a commercial society, to matters of the heart and thus anchored masculine public status in private romantic conduct. Although male promiscuity is never interrogated like women's sexual reputation, the fact that the action punishes men for perfidy can also be seen as acting as a restraint on male sexual entitlement.

21 Joseph Chitty, A Treatise on the Law of Contracts, and Upon the Defences to Actions Thereon (H Sweet, 1863) 491.

22 Ibid, 490.

23 Breach of promise of marriage formed one of the exceptions to the reform of laws stipulating imprisonment for debt in the 19th century, which sparked much debate. See, for example, 'The Satirist', Sydney Gazette and New South Wales Advertiser, 27 June 1837, 2; 'Anomalies of the New Bankruptcy Act', South Australian Advertiser, 26 May 1864, 3. 


\section{Breach of Promise of Marriage in Colonial Australia}

Australian judges and magistrates modified many of Chitty's requirements. The requirement that the promise be renewed after sex was never raised nor was the question of whether the woman had accepted the offer. The central legal issue in all cases turned on what behaviour constituted a promise to marry and whether the broken promise was justified by the woman's immoral conduct. Related to this was the definition of immoral conduct. The fact that Chitty limited the meaning of 'immorality' to sexual chastity outside of a continuous promise of marriage did not preclude one woman from being interrogated over whether she laughed immoderately in public, wore men's clothing or was overheard at a ferry wharf saying: 'Dammit don't let the boat go!'24

The figures collected from my database suggest that in practice breach of promise of marriage was overwhelmingly a feminised action: there were eight instances of male plaintiffs and they never successfully claimed damages. In this respect, my figures resemble Lettmaier's study in Britain from 1800-1940 which had only seven male plaintiffs. ${ }^{25}$ Furthermore, in my study women were overwhelmingly successful in prosecuting male suitors, with only 7 per cent of cases awarded to defendants and 76 per cent for the plaintiff. The rest were either settled out of court, non-suited, struck out or set aside. The vast majority of litigants were white Australians and 82 per cent of the plaintiffs came from poor families who aspired to respectability, 11 per cent were respectable and 4 per cent were wealthy. Unlike England, poor women were just as likely to win an action against wealthy men as they were against men in their own class but the majority of actions involved intra-working class disputes. These figures are partly a product of necessity: working class women like Stewart needed financial compensation for lost wages and relief for raising a child. Recoiling in the glare of the public was not a luxury they could afford.

Judged in terms of the number of cases brought to court, the action reached its height in Australia in the 1890s, the very moment when it started to decline in England. However, the average damages received peaked in the mid-1870s and 1880s and then declined sharply in the late 1880s and 1890s, as they did in England. Many of the cases heard in Australia ended up in the bankruptcy court and in one case the suitor spent over a year in prison. ${ }^{26}$ The rise in cases in the $1890 \mathrm{~s}$ in Australia and, inversely, the decline in damages awarded, may be attributable to the

24 Heals $v$ Mellersh (1842) WASC, WH Mackie (Esq), cited in Perth Gazette and Western Australian Journal, Saturday 16 April 1842, 2-3.

25 Lettmaier, above n 5, 28.

26 Keller $v$ Kimmins (1887) QLDSC. In this case Keller successfully sued Kimmins for 500 pounds and upon being unable to pay it, Kimmins was sent to Brisbane Gaol. After languishing in prison for 15 months, a public campaign developed urging his release which finally came through a petition to the Governor. See Maryborough Chronicle, Wide Bay and Burnett Advertiser (Queensland), 28 December 1888, 2. 
depression: more women seeking assistance and less money available to pay them. It may also be because of growing antipathy on the part of the male jury and magistrates or judges towards an action that was seen to be biased towards women, implicated in the women's rights movement or anachronistic in a world where more women were engaging in paid work. ${ }^{27}$

South Australia appears as an interesting deviation from the other colonies, and indeed from the rest of empire in that from 1862 they allowed breach of promise to be sued in the local courts. As Mr Waterhouse, MP argued at the time, if a female were deceived by some rustic swain ... why shouldn't she be able to bring a cheap action to recover damages?'28 This meant that almost as many women sued in South Australia as Victoria - a State with almost five times the population (in the 1861 census Victoria had 529,653 and South Australia had 124,159). ${ }^{29}$ Unlike every other colony, more women with illegitimate children sued in South Australia than women without children. If we were to count illegitimate children who died then it was over double the number of childless women. Unlike other colonies, with the exception of Queensland, the majority of South Australian cases came from country towns. The already porous division between formal law enacted in court and informal law governed by communal norms, was even more so in country towns, where courts could take on the character of an argument at the pub or a local theatre. Further, local courts were courts of equity and good conscience which meant that the strict rules of law need not be followed: ${ }^{30}$ for instance, plaintiffs and defendants were interrogated long before changes in the Evidence Act allowed. The jury, audience, litigants and magistrates knew each other and court often worked to convert affective punishments such as shame and social exclusion into legal financial remedies.

The idea that the offence involved false pretences assumed heightened significance in colonial Australia; a place, as Russell and McKenzie have argued, where lives could be made and remade and where verification of identity could take up to six months by way of a letter to Britain. ${ }^{31}$ Categorising breach of promise as an act of fraud also reveals a contemporary awareness of the performativity of masculinity. Fraud is normally characterised in law as falsely claiming an identity or status; in Blackstone's Commentaries it appears as a person doing something in the

27 See, for example, 'How to Quantify Pain and Suffering', West Australian, 19 May 1892, 2 and 'Women's Rights', Australian Town and Country Journal, 14 October $1893,34$.

28 Waterhouse MP, The Parliament, Legislative Council, 3 September 1861 cited in South Australian Register, 4 September 1861, 2.

29 Beth Wright, Colonial Censuses and Musters (17 April 2013) Australian Bureau of Statistics, <http://abs.gov.au/ausstats/abs@.nsf/Lookup/2071.0Feature+Articl e4July+2011>.

30 Shaunnagh Dorsett, 'How Do Things Get Started? Legal Transplants and Domestication: An Example from Colonial New Zealand' (2014) 14 New Zealand Journal of Public and International Law 103.

31 Penny Russell, A Wish of Distinction: Colonial Gentility and Femininity (Melbourne University Press, 1994); McKenzie, above n 7. 
name of another to dispossess the person with whom they're transacting of a good. ${ }^{32}$ In breach of promise, the good was the woman's chastity, but who was the honourable gentleman whose name had been stolen? Was he a fictive sentimental persona that could be taken up and discarded by any lusty suitor? Didn't romance always involve idealised self-portraiture? Could an honourable man slide into a hoary Adonis as easily as Eve could slide into a strumpet? And in a shifting and uncertain colonial world, how were you to know whether your lover was who they said they were? How different was the 'I' who appeared in the love letter from the 'I' who wrote the love letter?

Designating breach of promise as an act of malice also created conceptual problems. Malice meant premeditation, in Blackstone's words it was 'an express evil design'. ${ }^{33}$ The evil in falsely promising marriage in exchange for sex lay partly in Christian teaching that sex was sinful and partly in the bourgeois solution to this sin: channelling sex into marriage. Dissoluble private marital vows meant public disorder. It meant uncontained sexuality that left physical traces in bastard children, ruined women and destitute single mothers. And yet companionate marriage, guaranteed by a long courtship where couples would unravel each other's authentic selves, rose to prominence during the Victorian era. ${ }^{34}$ It was buttressed by changes in divorce law that allowed couples to more easily end unhappy marriages. Breach of promise, however, allowed for no change of heart, transformed courtship into coercion and bound couples to marriage regardless of future suitability. As critics of the action often noted, the suitor may sometimes have been more rational than malicious. ${ }^{35}$

\section{Maintenance}

Legal treatises such as Blackstone and Chitty offered the courts no guidance on how to disentangle breach of promise of marriage actions from either maintenance claims or the action of seduction (which could be claimed by the father of a woman under 21 for loss of service on account of her pregnancy). For all that judges, like Justice Forster in Stewart v Duggan, declared breach of promise to be 'really about the loss of a husband' the figures suggest otherwise. Forty-four per cent of litigants in my database had illegitimate children, compared to 48 per cent who had no children. Of the 73 single mothers who sued for breach of promise of marriage, 69 won substantial damages and only four lost. In England, according to Frost, single mothers comprised a 'substantial minority'. ${ }^{36}$ In my figures they

32 William Blackstone, Commentaries on the Laws of England: in Four Books, Volume 4 (A Strahan, 15th ed, 1809) 156.

33 Ibid, 199.

34 See Karen Lystra, Searching the Heart: Women, Men, and Romantic Love in Nineteenth-Century America (Oxford University Press, 1989).

35 See, for example, 'The Profession of Matrimony', Kapunda Herald (South Australia), 5 February 1892, 4.

36 Frost, above n 4, 225. 
comprise almost half of all cases. Further, in maintenance cases such as Clifford $v$ Connolly ${ }^{37}$ or Geach $v$ Jones, ${ }^{38}$ the women gave evidence that they had informally settled for breach of promise of marriage and had been using that money as maintenance. In practice, maintenance claims and breach of promise were interwoven, with one usually preceding or following the other. Alternatively, in the 1891 case of Cornick $v$ Kinsella ${ }^{39}$ the plaintiff stated that she brought a maintenance action because she didn't have the funds to bring a breach of promise action. The magistrates in maintenance actions would often grant an amount conditional upon the verdict of the pending breach of promise action.

There was little consistency in how the courts separated the social fact that breach of promise worked as a form of maintenance from the legal fiction that it was confined to loss of marriage settlement. In the $1866 \mathrm{New}$ South Wales case of Grogan $v$ Hemmings ${ }^{40}$ the judge told the jury the issue was simply one of a breach of contract. They were not to take into account the seduction when awarding damages. A few years later in Compton $v$ Tyer, counsel admitted that the plaintiff 'was more activated by a desire to get money to keep her child than to obtain damages' although encouraged the jury to also award her damages as it was 'her own loss and her own shame'. ${ }^{41}$ His words are interesting for the imagined line that they draw between damages and money; the former designed to compensate women for loss of social status and the latter, crude money, required to raise a child. It's a choice of words that protects the sacred institution of marriage from the vulgarity of financial necessity. South Australia appears to have had the most consistent reasoning on the subject in viewing seduction as an aggravation of damages. Their approach is encapsulated in the 1868 case of Coote $v$ Tynan where counsel for the plaintiff argued that seduction in breach of promise of marriage cases called for retribution, 'no amount of damages would be excessive'. 'The local courts' he said 'were the protective guardians of the middle classes' and a substantial award would send a message to 'roving seducers and the community'. ${ }^{42}$ Thus an effeminised middle-class are pitted against a threatening nomadic working-class masculinity that's to be disciplined by a paternalistic court. The statement also suggests that cases involving single women were perceived to be as much about compensating women as they were about policing masculinities.

$37 \quad$ Clifford $v$ Connolly (1868) QLDSC, cited in Rockhampton Bulletin and Central Queensland Advertiser, 12 May, 1868.

38 Geach v Jones (1883) Adelaide Local Court, cited in Burra Record, 14 September $1883,3$.

39 Cornick v Kinsella (1891) QLDSC, cited in Morning Bulletin, 14 November 1891, 5.

40 Grogan v Hemmings (1868) NSWSC, cited in Maitland Mercury and Hunter River General Advertiser, 1 December 1866, 3.

41 Comptonv Tyer (1896) NSWSC, cited in Dubbo Liberal and Macquarie Advocate, 18 April 1896, 3.

42 Coote v Tynan (1868) Adelaide Local Court, Mr Lowe, see Southern Argus (Strathalbyn), 24 October 1868, 2-3. 
Why did single mothers turn to breach of promise of marriage for financial redress and why were the courts so willing to reward them? The courts, to my mind, were seeking to shift the financial burden of illegitimate children from the public to the father in situations where women could not support their families through work and/or failed to gain payment from her partner through other legal avenues, such as maintenance. There was no common law obligation for a father to support his illegitimate children. ${ }^{43}$ Further, as the English Poor Law was not transplanted to Australia, there were no liable relative procedures as existed in the United Kingdom. ${ }^{44}$ In a broader context of social welfare at the time, no statute existed to make the relief of the poor obligatory upon the respective colonies. Instead, relief was granted through private charities or government institutions that operated with varying degrees of success across the colony, dependent upon the government's willingness to provide funding. ${ }^{45}$ For instance, in Van Diemen's Land, benevolent societies akin to those also operating in Sydney were in existence from the 1830s onwards and yet government refused to fund them, as they did in New South Wales. ${ }^{46}$ As a result, they were limited to outdoor relief. Similarly, government funding in Victoria for benevolent institutions was markedly less than in New South Wales. ${ }^{47}$ As the century came to a close and the depression of the 1890s worsened, destitute women suffered disproportionately. According to Shurlee Swain's history of single mothers only 100 of the 2000 illegitimate children born each year were able to be accommodated in Melbourne's charities in the 1890s. ${ }^{48}$

If any of these women had turned to the law to seek maintenance, their chances of success were low in spite of legislative protections. Each colony had legislative provisions forcing fathers to pay maintenance for illegitimate children. Taking South Australia as an example, the law provided two remedies. There was a criminal remedy under the Police Act 1869-1870 (SA) s 63 which stated: 'every person leaving his wife or child chargeable ... to the public, or without the means of support to them than public charity is ... liable to be imprisoned with hard labour for not exceeding three calendar months'. ${ }^{9}$ The civil remedy was provided in the Destitute Person's Act 1881 (SA) s 14 which made either of the parents liable to support an illegitimate child subject to the proviso that the mother's evidence to paternity be corroborated 'by other and independent testimony'. Although South Australia's social welfare system was unique, the legal mechanism governing maintenance bore parallels to the other

43 Anthony Dickey, Family Law (Lawbook Co, 4th ed, 2002) 463.

44 Ibid, 463. For commentary on the United Kingdom's liable relative procedures see: Stephen Parker, 'Rights and Utility in Anglo-Australian Family Law' (1992) 55 Modern Law Review 311, 327.

45 Dickey, 1987, above n 12, 1-23.

46 Ibid, 18-19.

47 Chitty, above n 16.

48 Swain, above n 9, 154.

49 Police Act 1869 (SA) s 63. This was modelled on the English Fugitive Offenders Act (c 69, 44 and $45 \mathrm{Vic})$. 
colonies where acts such as the Deserted Wives and Children Act 1840 (NSW) s 8 or the Maintenance Act 1837 (Tas) s 6 covered maintenance for illegitimate children. Yet in spite of these provisions single mothers found it difficult to win maintenance. First, establishing paternity was an arduous task. In Mitchelmore $v$ Jackson $^{50}$ the Court held that the effect of the proviso was more stringent in Australia than in England. A maternal grandmother's testimony, for instance, was not considered to be independent. Secondly, a maintenance order was only enforceable in the colony in which it was made, which meant that men could with ease escape their obligations through slipping across colony borders. ${ }^{51}$ Thirdly, proceedings to make putative fathers liable could not be instituted until after the birth of the child. These problems also beset single mothers in other Australasian colonies. ${ }^{52}$ According to Swain, a sample of cases brought before the Magistrates Court in the 1850s showed that only 50 per cent were successful. ${ }^{53}$

The fiction that breach of promise of marriage was exclusively about redressing the loss of a husband meant that establishing paternity was not an essential element of the breach of promise action. In the case discussed below, Frances Titley lost her maintenance action on the grounds that she couldn't establish paternity but won significant damages in breach of promise of marriage. A writ of capius, which often accompanied the action for breach of promise, meant that the suitor could not abscond, and the lump sum payment meant that women would not be reliant on the goodwill of a man to make weekly payments. The meagre average of 10 shillings per week awarded for maintenance ${ }^{54}$ can also be contrasted to the much more lucrative 100 pounds average for breach of promise of marriage. When cast in this light, the large number of single mothers using the action seems understandable. For the courts its advantages lay displacing the financial burden of caring for a child from the community to the fathers.

\section{Titley v Moltine: A Case Study}

Let us now turn to a breach of promise of marriage case to add some flesh to the skeletons contained in the data. Frances Titley - 'virtuous, extremely modest, thoroughly respectable, straightforward without any forwardness' - was, in spite of herself, a prime candidate for a breach of promise of marriage. Orphaned at the age of nine, she was raised by her aunt in Tasmania until she moved to Emerald Hill at the age of 22 on a promise of marriage to a Mr Draper. As was customary at the time, Draper asked Frances to find somewhere else to live until he had enough

$\overline{50 \quad \text { Mitchelmore }} v$ Jackson cited in 'Second and Final Report of Commission Appointed to Report on the Destitute Act', Adelaide, E Spiller Government Printer, 1885.

51 Ibid.

52 Ibid.

53 Swain, above n 9, 164.

54 Ibid, 165. 
money to marry and supply a house, and so Frances accepted an offer to perform household labour in exchange for five shillings per week from Mr Moltine the recently widowed owner of the local grocery store. Within 10 days of her appointment, according to Frances' testimony, Mr Moltine had proposed marriage and Frances had refused on account of her engagement. A few days later, Mr Moltine went into Frances' room and had sex with her without her consent. 'I could not scream as I had become paralysed with fright,' she told the court. 'He asked me to keep secret what he had done for it was his intention to make me his wife.' He bought her a ring, clasped her by the hand and proposed to her saying that he would not let her go until she agreed. She consented, subsequently broke off the engagement with Draper and the marriage was arranged for six months' time. Frances describes the relationship as follows: 'he was able to enter my room as he would not have the doors locked' and 'he told me he would treat me or advise me like I was his own child'. He said that 'in the sight of God I was as much his wife as if the ceremony had been repeated a dozen times over'. Frances soon became pregnant after which Moltine announced that he now wanted to wait 12 months before marriage. When Frances' belly swelled, Moltine bundled her off to her aunt in Tasmania lest knowledge of her condition 'injure his business'. He promised to send money, he promised to come to Tasmania to marry her and he demanded very specifically that she write him no letters. Neither the money nor Moltine arrived, and the one letter that Frances sent him telling him of the birth of their child went unanswered.

The machinery of community regulation ground into action with the birth of her child. 'Sir' began her aunt's letter to Moltine, 'Miss Titley ... has been the poor victim of a bad licentious man, such as you prove in disgracing a large circle of relations and friends, we take it sorely, having brought Fanny up, and a more virtuous young woman I never met: but in an evil hour she was led astray, you promising marriage to her.' The aunt described how Frances' health and status had suffered. She also established paternity: 'the child is the image of yourself ... the dear infant must be cared for by you as its father'. She then appealed to his sentiment: 'surely your feelings will be stirred up to help her. What can she do to keep herself and baby? Why did you not fulfill your promise?' The letterwith its attestation of female virtue blasted by a promise of marriage, its designation of the defendant as licentious, its proof of paternity and its quantification of social and financial loss-mimicked a plea in breach of promise of marriage. It also carried the threat of coercion. 'Her brother intends calling on you to see what you propose doing', she warned. The brother visited Moltine twice and each time threatened that he marry her or 'it might be worse for one or the other of us'. Moltine interpreted the aunt's letter through the lens of law and hired a solicitor to write his response. 'Madam' it began, 'you tax him with being the father of [Miss Titley's] illegitimate child, a statement which, as an honourable man, he truthfully and most emphatically repudiates ... He also says when your niece first came to his house he was suffering from an utter bereavement, 
having just lost one of the best of wives and under those circumstances it was not either likely or natural that even the most sensual of men would so soon try to ruin a girl ... you pronounce him "bad and licentious" but he is the very opposite, and would not wrong any girl under the pretence of marrying her.' He said that Moltine remained in Emerald Hill to brave any disgrace that the action may bring him and hoped that the aunt would not 'judge him for the wrongs of others,' namely Mr Draper who Moltine claimed was in fact the father.

Frances returned to Emerald Hill, sued Moltine for maintenance and lost on the grounds that no man could be taken to be the father of an illegitimate child unless other evidence than that of the mother be brought forward. Unlike Duggan, who signed off his letters with kisses for 'his son', Moltine was careful to never provide proof of paternity in letters. On 24 November 1875 she sued Moltine for 1000 pounds for breach of promise of marriage. This time, Frances substituted love letters with the testimony of family and friends. Moltine, in turn, repeated his claims in his letter, but the court was unconvinced and found for Frances for 200 pounds. Three months later she sued him again for maintenance and this time won 10 shillings per week. As the Australasian reported at the time, 'lovers of justice would be pleased'. ${ }^{55}$

Titley is typical of most female breach of promise litigants in that she is from a poor but respectable family, while Moltine, as a grocery store owner, is wealthier than most of the defendants in my survey, who tended more towards being labourers or farmhands than business or propertyowners. I have chosen this case less because of its representative status than the interesting way in which it reveals three intersecting levels of order whose structures produce various models of masculinity. The first is that of patriarchy - a kind of nightly law that thrives on the clandestine. This is Moltine in his home with no locks, with uninhibited access to the bodies of women whom he advises as children and casts out as reproductive adults. This is Moltine disregarding public, secular marriage ceremonies and instead appealing exclusively to the authority of God; it is his preference for the ineffability of an oral promise over the trace of a written letter. It would be tempting to argue that this patriarchal model of masculinity is disciplined and punished by law or communal norms, but I am not so certain. Moltine, like numerous other defendants in breach of promise actions, is never charged with rape and the idea of him advising his wife like a child was a common trope in 19th century romance fiction, albeit one that battled against women's innate moral superiority. The reason patriarchy comes to offend formal and communal law is that Moltine fails to convert his private romantic vows into public legal form and in so doing fails to perform his role as husband, breadwinner and father. His inability to fit his sentimental feelings into an appropriate masculine gender role is what gives rise to an action against him at the community level as a 'bad and licentious man' and at law as a 'roving seducer'.

$55 \quad$ Titley v Moltine (1875) VICSC, per Barry J. See Argus (Melbourne), 30 October 1875 . 
The second level of order is that of communal regulation: a machinery of letters, watchful eyes, raised fists, serendipitous interrogations on street corners, injured businesses and appeals to masculine honour. In the 1870s courtship for most 'respectable' women was still largely conducted under family supervision for the precise reason that Frances - orphaned and friendless in a town far from home-makes clear: women were vulnerable to the ill-intentioned and the social and economic consequences of pregnancy were dire. Women obviously suffered scorn for a lack of chastity and their shame was transmissible: spread throughout their extended family. This is where the secrecy preferred by Moltine had a common ally in the secrecy demanded by respectable culture when rigid codes of sexual morality were transgressed. As Deborah Cohen has argued 'family secrets were a strategy of defence and protection, a means of guarding a black sheep as well as the family's reputation'. ${ }^{56}$ This was also evident in the case of Stewart v Duggan when Stewart complained that 'people had turned against her on account of the child' and Duggan responded by saying that he had lied to their friends in Teralba and even certain family members: "everybody thinks that we are married and that you are with me'. ${ }^{57}$ As his words suggest, marriage could banish the secret. Honour worked as salvation; being true to your words, honouring your promise, meant erasing the lies in between.

Communal regulation worked at the level of emotion: it sought to enforce its judgments through appealing to masculine feeling. Frances' aunt does not threaten legal action nor does she ask directly for money to raise the child. Rather law and economics are the substrata beneath her emotional exhortations: 'surely your feelings must be stirred up for her' she cries, 'the infant must be cared for by you as its father'. Feeling and a model of fatherhood situated in care generates legal and fiscal responsibility. It is for this reason that Moltine responds through his solicitor who in turn accepts her sentimental framework. He refutes her charge on the grounds of grief: bereavement, he argues, quarantines even the most sensual man from sexual impulses. He establishes Moltine as honourable and honest; terms which obtain their meaning through definition against men who act under false pretence. Designating Moltine as sensual or licentious also had obvious commercial effects, as he states at least three times to Frances: knowledge of their romantic engagement would injure his business. Public honour in trade had private, romantic foundations.

If the emotional pleas that we see at the community level rested on law then it could equally be argued that law was saturated in sentiment and court was a space where conflicting models of masculinity and appropriate expressions of emotion were debated. The jury in Titley $v$ Moltine, as in countless other cases, were appealed to by counsel for the plaintiff as 'fathers and husbands'; 'they would not be true to themselves as head

56 Deborah Cohen, Family Secrets: Living With Shame from the Victorians to the Present Day (Penguin, 2013).

57 Stewart v Duggan (1899) NSWSC, cited in above n 3, Foster J. See also, Newcastle Morning Herald and Miners' Advocate (Newcastle) 16 April 1890, 7. 
or members of families if they did not by their verdict signally mark their abhorrence of such heartless conduct'. Drawing upon a vast repertoire of 19 th century romantic literature featuring orphaned daughters or daughters of widows, this strategy always guaranteed success. The court - as a 'guardian of middle class manners' - stepped in as the absent father to protect the daughter and punish the seducer. The counsel for the defence, on the other hand, appealed to them as 'men of reason'. The question was simply one of contract: had a promise been made? The Judge also took this approach but more out of an effort to protect the solemnity of the court from what often appeared to be theatrical farce. As Dickinson J said in Field $v$ Nelson: This 'was not a Court of Romance, nor a Court of Sentiment, but a Court of Law. It was alleged that a contract had been made, and a contract broken; and he trusted that the jury would come to the consideration of the amount of damages sustained thereby, with the same calm and dispassionate feeling as though the question affected a ton of hay or a pound of butter'. ${ }^{58}$ Yet arguments that focused on contract rarely won and in numerous cases juries simply ignored the advice of judges and awarded large, clearly vindictive, damages.

The defendant, it could be argued, occupied the role of transgressive manhood - he was a 'gay lothario', a 'hoary Adonis', a 'black guardian', a 'scoundrel', a 'perfidious swain', a 'peddler of false feeling'. His failure to honour his promise of marriage made him a dishonourable man, as untrustworthy in the commercial market as he was in the marriage market. It was a distinctly middle class model of masculinity, as demonstrated in the 1895 case of Fletcher $v$ Headlam, where the aristocratic defendant was accused of 'pleasing his father rather than being honourable and marrying her like a man'. He retorted that he always intended to 'earn his own crust and support her and the child'. ${ }^{59}$

Although the defendant almost always lost, popular opinion regarded him with ambivalence - one that increased with divorce law reform, women's greater public freedoms and a shift in courtship practices that allowed greater autonomy to couples. Was he a peddler in false feeling or was he in fact simply being true to his feelings? As the Maryborough Chronicle asked in 1870: 'a woman brings an action for breach of promise because a man having promised to marry her finds after knowing her better that he cannot perform his part of the contract faithfully'. ${ }^{60}$ Here to marry without feeling appears to be the act of fraud and the breach to be an act of faith.

58 Field v Nelson (1850) NSWSC, cited in Freeman's Journal Sydney (Sydney), Dickinson J, 4 July 1850, 5.

59 Fletcher $v$ Headlam (1883) TASSC, cited in Geelong Advertiser (Geelong), 5 April $1883,3$.

60 Maryborough Chronicle, Wide Bay and Burnett Advertiser (Queensland), 14 May $1870,4$. 


\section{CONCLUSION}

When examining colonial breach of promise of marriage cases, one would not expect to find courts populated by squalling infants. After all, the woman's lack of chastity was a complete defence to the action. But in Australia these cases comprised almost half of those brought to court, which suggests that the women who were bringing them were clearly claiming for more than injured feelings. In a place without poor laws or parishes and where maintenance was difficult to enforce - where men had an entire empire or continent to disappear into - breach of promise offered women a lump sum payment at the threat of bankruptcy prison. While I have examined the broken romantic promises that made it to court, there seems to be evidence to suggest that ill-fated couples were informally forging these agreements as well. ${ }^{61}$ But for contemporaries, the issue was not framed in terms of single mothers, but rather as a problem of roving seducers. It was a forum that exposed the economic foundations of marriage and care-work and that measured men according to a sentimental, fiscally responsible paternal norm and punished them for their transgressions.

61 See, for example, the case of Simpson $v$ Offer (1870) Tas Police Court, cited in Launceston Examiner, 24 May 1870, 5. This was a case for maintenance where it was stated that the 'Defendant paid her some money for breach of promise of marriage upon which she had been living'. 